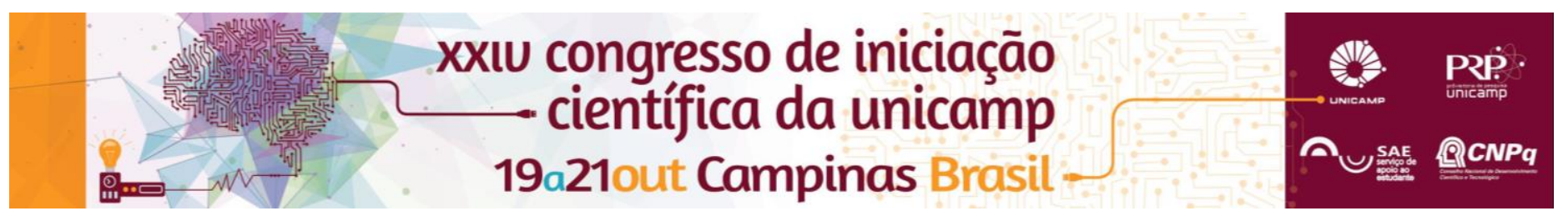

\title{
Patents Trajectories Analysis: Enzymatic Hydrolysis and Bioethanol.
}

\section{Pedro L C Mendonça (IC) \\ José M F J da Silveira (PQ).}

\section{Abstract}

The purpose of this study is to analyze the dynamics of innovation in second-generation ethanol seeking to observe how a portfolio of patents held by one or more biotech companies indicates the creation of barriers to entry and which impacts on the development of the biofuels sector.

\section{Key words:}

enzymatic hydrolysis, trajectories, patents.

\section{Introduction}

The phenomenon of global warming is directly related to the use of fossil fuels. In this scenario, the development of biofuels not only will help to reduce the damage to nature, but also leaves room for the development of a new industry, the bio-economy based on large $R$ \& $D$ investments in biotechnology and biobased chemicals.

The second-generation ethanol is one of many biofuels that are currently being developed; its commercial viability depends on the development of conversion technologies from lignocellulosic biomass into ethanol

\section{Results and Discussion}

According to Campos (2008), the development of a commercial agro-biotechnology product is quite risky and it demands a set of articulated knowledge involving enabling technologies that are under the control of different companies. It is trying to protect the investment that comes the need for defense mechanisms of intellectual property such as patents.

Patents and intellectual rights protection mechanisms are key sources of information for technology foresight studies. Companies can use their patents for other reasons besides protecting their investments. They can use it to monopolize the main technologies to stifle innovation of its competitors, effectively creating monopolies for their own product lines. From the cross-referencing of one patent with subsequent patents, it is possible to build graphical networks composed by patents and links, (citation of patents). These relationships, taking the form of graphical networks are analyzed according to a combination of network indexes.

Three methodological steps performed the analysis of the dynamics of innovation related to obtaining secondgeneration ethanol process approach of patent citation networks; access to patent databases and the analysis of the top assignees; lexicographic analysis.

\section{Conclusions}

The analysis of the four networks of patents identified to convert biomass into ethanol suggests that it has not been set yet a clear "winner" technology. The R \& D process of second-generation ethanol is an emerging technological trajectory. However, it is possible to observe the presence of large biotech companies acting as important players in the market.

We should pay attention to the possibility that as the $R$ \& $D$ process in ethanol second generation set consolidated technological trajectories, biotech patents might be subject of patent trolls processes. There are already major legal disputes involving patents for production of secondgeneration ethanol. For example, the legal dispute between Novozymes and Danisco AS.

\section{Acknowledgement}

The author is grateful to the CNPq-PIBIC for the award of a research scholarship during the tenure of which this work was carried out.

CAMPOS, Rafael Ribeiro. Redes de direito de Propriedade Intelectual na agrobiotecnologia: modelagem e mensuração de eficiência, 2008. 70f. Monografia (Graduação em Ciências Econômicas) - Instituto de Economia, Universidade Estadual de Campinas, Campinas, SP, 2008

DAL POZ, Maria Ester; SILVEIRA, José Maria Ferreira Jardim e MASAGO, Fábio. TECHNOLOGY FRONTIER ON BIOENERGY: ANALYSIS OF TWO NETWORKS OF INNOVATION. Anais do XL Encontro Nacional de Economia, ANPEC. 2012 Disponível em http://www.anpec.org.br/encontro/2012/inscricao/files I/i8-

782b43e603978a6df53dcb1cb92350ad.doc> . Acesso em 30 de julho de 2014. MASAGO, Fábio Kenji. Odyssey's: sistema para análise de documentos de patentes. 2013. 124 p. Dissertação (mestrado) - Universidade Estadual de Campinas, Instituto de Computação, Campinas, SP. Disponível em: <http://www.bibliotecadigital.unicamp.br/document/?code $=000909740$ >

Acesso em: 28 jul. 2014 